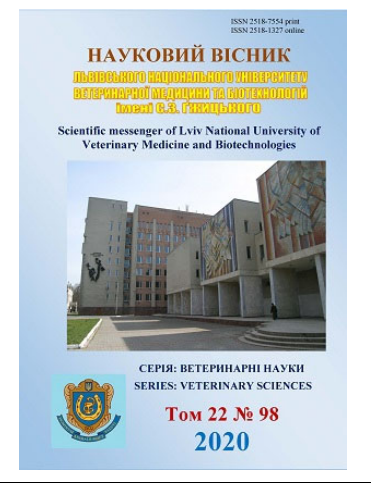

Науковий вісник Дьвівського національного університету ветеринарної медицини та біотехнологій імені С.3. Гжицького. Серія: Ветеринарні науки

\author{
Scientific Messenger of Lviv National University \\ of Veterinary Medicine and Biotechnologies. \\ Series: Veterinary sciences
}

doi: $10.32718 /$ nvlvet 9822

https://nvlvet.com.ua/index.php/journal

UDC 636.51.58.087.09

\title{
Content of natural antioxidants depending on typological features of autonomous regulation in chickens
}

\author{
E. O. Shnurenko, A. A. Studenok, V. I. Karpovskiy, V. O. Trokoz
}

National University of Life and Environmental Sciences of Ukraine, Kyiv, Ukraine

Article info

Received 23.04.2020

Received in revised form 26.05.2020

Accepted 27.05.2020

National University of Life and Environmental Sciences of Ukraine Heroyiv Oborony Str., 15, Kyiv, 03041, Ukraine.

Tel: $+38-098-423-96-07$

E-mail: ellina.fedchenko@gmail.com, karpovskiy@meta.ua, artemstudenok@gmail.com, trokoz@nubip.edu.ua
Shnurenko, E. O., Studenok, A. A., Karpovskiy, V. I., \& Trokoz, V. O. (2020). Content of natural antioxidants depending on typological features of autonomous regulation in chickens. Scientific Messenger of Lviv National University of Veterinary Medicine and Biotechnologies. Series: Veterinary sciences, 22(98), 128-131. doi: 10.32718/nvlvet9822

Secondary antioxidants inhibit the development of chain reactions of peroxidation of unsaturated fatty acids. In turn, the autonomous nervous system regulates the functioning of internal organs and affects the intensity of metabolic processes in the animal body. However, the question of the content of natural antioxidants in birds, depending on the typological features of autonomous regulation, is not well understood. The purpose of the work was to research the content of natural antioxidants depending on the typological features of the tone of the autonomic nervous system in chickens. For research, chickens of the 35-day-old Cobb-500 cross were used. A study of the typological features of autonomous tone in a research bird was carried out by recording an electrocardiogram and counting one hundred $R-R$ cardio intervals, which were processed by the method of variational pulsometry according to R. M. Baevsky. To determine the effect of autonomic nervous regulation types on the activity of secondary antioxidants in experimental birds, blood samples were taken and the content of tocopherol and retinol was determined. As a result of the researches, it was found that the content of tocopherol and retinol in vagotonic chickens of 35 days old was significantly higher by $13.4 \%(P<0.001)$ and $14.06 \%(P<0.01)$ than in sympathotonic chickens, respectively. Reliable correlations between the increase in tocopherol activity and the level of retinol in chickens with a sympathotonic type of autonomic nervous system were revealed. Determination of the content of natural antioxidants of chickens depending on the types of the atomic nervous system makes it possible to identify the bird with the highest stress resistance and antioxidant protection. This creates the conditions for the distribution of chickens depending on typological characteristics and makes it possible to identify chickens at an early stage of development; they need more vitamin supplements with antioxidant properties, as well as to prevent a decrease in growth due to the formation of oxidative stress during the entire growing period.

Key words: sympathotonics, vagotonics, normotonics, variational pulsometry, tocopherol, retinol.

\section{Вміст природніх антиоксидантів в залежності від типологічних особливостей автономної регуляції у курей}

\author{
Е. О. Шнуренко, А. А. Студенок, В. І. Карповський, В. О. Трокоз
}

Національний університет біоресурсів і природокористування Украӥни, м. Киӥв, Украӥна

Вторинні антиоксиданти перешкоджають розвитку ланцюгових реакцій пероксидного окиснення ненасичених жирних кислот. В свою чергу, автономна нервова система регулює роботу внутрішніх органів та впливає на інтенсивність обмінних процесів в організмі тварин. Однак, питання щуодо вмісту екзогенних антиоксидантів у птиці в залежності від типологічних особливостей автономної регуляиії є недостатньо вивченим. Метою роботи було дослідження вмісту природніх антиоксидантів залежно від типологічних особливостей тонусу автономної нервової системи у курей. Для проведення досліджень використовували курей 35 добового віку кросу “Кобб-500”. Дослідження типологічних особливостей автономного тонусу у дослідної птиці проводили иля- 
хом запису електрокардіограми та підрахунків ста $R-R$ кардіоінтервалів, які опрацювали методом варіаційної пульсометрії за P. М. Баєвським, щзо дозволило розділити всіх курей на три групи: симпатотоніків, нормотоніків та ваготоніків. Для визначення впливу типів автономної нервової регуляиії на активність вторинних антиоксидантів у дослідних птахів було відібрано проби крові та визначено вміст токоферолу та ретинолу. У результаті проведених досліджень встановлено, щьо вміст токоферолу та ретинолу у курей-ваготоніків 35-добового віку достовірно вища на 13,4\% (P< 0,01) та 14,06\% (P < 0,001), ніж у курейсимпатотоніків, відповідно. Виявлено достовірні корелячійні зв'язки між збільшенням активності токоферолу та рівнем ретинолу у курей із симпатотонічним типом автономної нервової системи. Визначення вмісту екзогенних антиоксидантів курей в залежності від типів АНС дає можливість виявити птицю із найбільшою стресостійкістю та антиоксидантним захистом. Це створює умови для розподілу курей в залежності від типологічних особливостей АНС та дозволяє на ранньому етапі розвитку виявити курей, що мають потребу в більшій кількості вітамінних добавок із антиоксидантними властивостями, а також попередити зменшення приросту внаслідок утворення оксидативного стресу впродовж всього періоду дорощування.

Ключові слова: симпатотоніки, ваготоніки, нормотоніки, варіаџійна пульсометрія. токоферол, ретинол.

\section{Вступ}

Автономна нервова система підтримує гомеостаз та регулює стабільність внутрішньої матричної рідини, необхідної для підтримання життя (Cannon, 1939). Встановлено, що показники обміну речовин в організмі сільськогосподарських тварин залежать від тонусу автономної нервової системи (Zhurenko et al., 2018). Високий рівень продуктивності сільськогосподарської птиці залежить від інтенсивність обмінних процесів, що сприяє швидкому засвоюванню поживних речовин, ранній скоростиглості та високій продуктивності (Kyryliv et al., 2015). Однак, ведення галузі птахівництва включає ряд технологічних операцій, що викликають надмірне напруження пристосувальних систем та розвиток стресу (Shevchuk et al., 2018).

Найбільш загальна і найдревніша реакція клітини на стресові події - це посилення продукції енергії електрон-транспортними системами мітохондрій i мікросом із збільшенням вживання кисню. Внаслідок бурхливого посилення окиснювальних реакцій та пошкодженні клітинних мембран утворюється маса активних форм кисню (Ostapyuk \& Gutyj, 2020). У відповідь на активацію вільнорадикального окиснення і ліпідної пероксидації зростає активність системи антиоксидативного захисту. Система антиоксидантного захисту виступає як найважливіша внутрішня сила протидії стресовим ушкодженням і порушенням (Lavryshyn et al., 2016). До основних жиророзчинних антиоксидантів належать: $\alpha$-токоферол, менш активні B-, у- i ô-токофероли і токотриєноли, які захищають ліпідний шар плазматичних, мітохондріальних, ядерних мембран, ліпопротеїди крові і лімфи, а також вітамін А (ретинол, ретиналь, ретиноєва кислота i провітамін бета-каротин), який захищає клітинні i тканинні мембрани, ліпопротеїди, сітківку ока. Введення антиоксидантів зовні, з харчовими продуктами i фармпрепаратами, поповнює ендогенні їх резерви, збільшує захисну активність системи, забезпечує утримання стресу у фізіологічних рамках (Polumbryk et al., 2014).

Саме тому метою даного дослідження $\epsilon$ визначення активності жиророзчинних антиоксидантів в залежності від типологічних особливостей автономної нервової системи у курей.

\section{Матеріал і методи досліджень}

Для створення піддослідної групи було відібрано 24 курей м'ясної продуктивності кросу “Кобб 500", віком 35 діб. Дослідження проводились на птахофермі Миргородського району с. Новооріхівка із підлоговим типом утримання на глибокій підстилці.

На першому етапі досліджень визначали типологічні особливості автономної нервової системи. Для цього у кожної курки було знято електрокардіограму за допомогою електрокардіографа ЕКЗТ-01-“Р-Д”, використовуючи електроди типу “крокодил”. Для запису електрокардіограми було обрано мінімально допустиму швидкість руху стрічки, яка становила 50 мм/c, 1 мB (Reddy \& Sivajothi, 2017). Зняття даних електрокардіограми проводили протягом 20-30 секунд. Отримані електрокардіограми обчислювали методом варіаційної пульсометрії за P. M. Баєвським шляхом підрахунку ста R-R кардіоінтервалів у стані спокою (Baevskyi et al., 1984). При цьому визначали два основних показники: моду (Мо) та амплітуду моди (Амо).

Таким чином, якщо мода дорівнюе $0,14-0,16 \mathrm{c}-$ тварину відносять до симпатотоніків, 0,16-0,17 с нормотоніків або $0,18-0,21 \mathrm{c}-$ до ваготоніків. Так як частота серцевих скорочень у птиці вища ніж у людей (від 120 уд. за хв), то показники моди були скориговані шляхом п’ятикратного збільшення, завдяки чому отримані результати можна було легко співвідносити 3 показниками, які використовують у гуманній медицині: нормотонічний тип $-0,8-0,9$ с; симпатикотонічний $-0,5-0,8 \mathrm{c}$; ваготонічний $-1,0-1,2$ с. Амплітуду моди використовують як додатковий параметр для уточнення тонусу автономної нервової системи: симпатотонія - > $45 \%$, нормотонія - 40-45\%, ваготонія $<40 \%$. За отриманими результатами дослідна птиця була поділена на три групи відповідно до тонусу AHC: симпатотоніки, ваготоніки та нормотоніки.

Другий етап досліджень включав:

- відбір проб крові з підкрилової вени (Nasonov et al., 2014) у курей 35-добового віку.

- визначення рівня активності екзогенних антиоксидантів - токоферолу та ретинолу - в плазмі крові (Levchenko et al., 2010) в залежності від типів АНC у курей.

- Статистичну обробку отриманих результатів за допомогою пакету аналізу даних в програмі Microsoft Excel 2016. 


\section{Результати та їх обговорення}

Встановлено, що на момент 35-добового віку у групи курей-ваготоніків рівень токоферолу в плазмі крові становив 27,917 мкмоль/л, нормотоніків 25,719 мкмоль/л, а у симпатотоніків - 24,175 мкмоль/л. Таким чином, у курей групи симпатотоніків та нормотоніків рівень токоферолу в плазмі крові був меншим відповідно на 13,4\% (P < 0,01) та 7,87\% (P<0,01), ніж у курей-ваготоніків (рис. 1). Це вказує на вплив ваготонічного типу АНС на здатність до накопичення вітаміну E, а отже і на посилення активності антиоксидантного захисту ліпідного шару мембран клітинних органел завдяки його антиоксидантним властивостям.

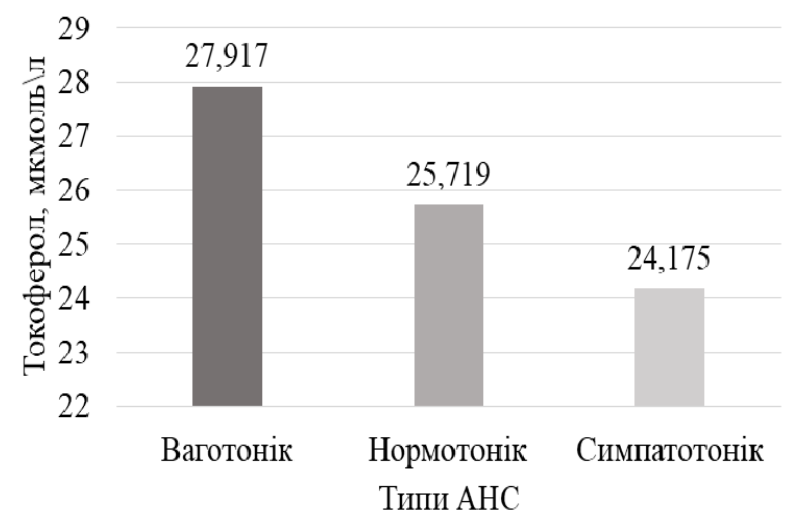

Рис. 1. Рівень токоферолу в плазмі крові в залежності від типів АНС у курей

Рівень ретинолу у плазмі крові курей ваготонічного типу автономної нервової регуляції складав $0,932$ мкмоль/л, що на 8,37 \% (P $\leq 0,001)$ та 14,06 \% $(\mathrm{P} \leq 0,05)$ більше за курей-нормотоніків та симпатотоніків, відповідно (рис. 2). Антиоксидантна дія ретинолу зумовлена участю у синтезі глутатіону та ефективній нейтралізації вільних радикалів, ксенобіотиків та деяких канцерогенних сполук. Такі властивості вітаміну А в сукупності з високим рівнем токоферолу у курей-ваготоніків свідчить про найвищий рівень антиоксидантного захисту, що складає міцний фундамент для вищого імунного статусу та приросту у таких птахів.

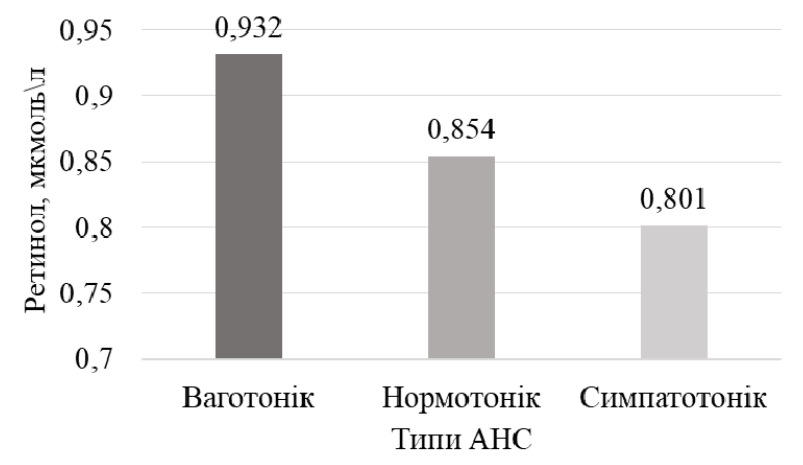

Рис. 2. Рівень ретинолу в плазмі крові в залежності від типів АНС у курей
Токоферол запобігає прояву прооксидантних властивостей вітаміну А шляхом його відновлення, тому що здатний захищати подвійні зв'язки ретинолу від окиснення та утворення високоактивних вільнорадикальних продуктів. Так виявлено прямі кореляційні зв'язки між рівнем токоферолу та ретинолу у плазмі крові курей-симпатотоніків ( $\mathrm{r} \geq 52 * *)$, що свідчить про більш тісний зв'язок та взаємовплив вітаміну А та Е у цієї групи птахів. При цьому кореляційних зв'язків між досліджуваними вітамінами у ваготоніків та нормотоніків не виявлено.

Отже, результати досліджень вказують на те, що тонус автономної нервової системи певним чином впливає на показники, що характеризують рівень природніх антиоксидантів у курей-бройлерів. Таким чином, виявлено стабільно найвищий вміст токоферолу та ретинолу у курей-ваготоніків, що обумовлює необхідність подальшого дослідження їх взаємозв'язків з іншими компонентами антиоксидантного захисту в залежності від типів автономної регуляції.

\section{Висновки}

1. Виявлено, що рівень природніх антиоксидантів в плазмі крові у курей відрізняється в залежності від типів автономної нервової системи.

2. Встановлено, що у курей 3 переважанням ваготонічного типу регуляції рівень токоферолу вищий ніж у курей групи симпатотоніків та нормотоніків відповідно на 13,4 \% (P < 0,01) та 7,87 \% $(\mathrm{P}<0,01)$.

3. Рівень ретинолу в плазмі крові курейваготоніків на 8,37\% $(\mathrm{P} \leq 0,001)$ та $14,06 \%(\mathrm{P} \leq 0,05)$ більше за курей-нормотоніків та симпатотоніків, відповідно.

4. Достовірно встановлено кореляційний зв'язок між рівнем токоферолу та ретинолу у курейсимпатотоніків.

5. Таким чином, розподіл курей в залежності від типологічних особливостей автономної нервової системи дозволяє на ранньому етапі розвитку виявити курей, що мають потребу в більшій кількості вітамінних добавок із антиоксидантними властивостями, що дозволяє збільшити активність антиосксидантого захисту внаслідок утворення оксидативного стресу впродовж всього періоду дорощування.

\section{References}

Baevskyi, R. M., Kirillov, O. I., \& Kletskin, S. V. (1984). Matematycheskyi analyz yzmenenyi serdechnoho rytma pry stresse. [Mathematical analysis of changes in heart rate during stress]. Moskva: Nauka (in Russian).

Cannon, W. B. (1939). The Wisdom oft he Body. New York, NY: WW Norton

Kyryliv, B. Y., Ratuch, I. B., Gunchak, A. V., \& Fedorovych, E. I. (2015). Biolohichni ta metabolichni osoblyvosti riznykh vydiv silskohospodarskoi ptytsi [Biological and metabolic features of different species 
of poultry]. Scientific Messenger of LNU of Veterinary Medicine and Biotechnologies. Series: Agricultural sciences, 17(1), 71-80 (in Ukrainian).

Lavryshyn, Y. Y., Varkholyak, I. S., Martyschuk, T. V., Guta, Z. A., Ivankiv, L. B., Paladischuk, O. R., Murska, S. D., Gutyj, B. V., \& Gufriy, D. F. (2016). The biological significance of the antioxidant defense system of animals body. Scientific Messenger LNUVMBT named after S.Z. Gzhytskyj, 18, 2(66), 100-111. doi:10.15421/nvlvet6622.

Levchenko, V. I., Holovakha, V. I., \& Kondrakhin, I. P. (2010). Metody laboratornoi klinichnoi diahnostyky khvorob tvaryn. K.: Ahrarna osvita (in Russian).

Nasonov, I. V., Bujko, N. V., Lizun, R. P., Volyhina, V. E., Zaharik, N. V., \& Jakubovskij, S. M. (2014). Metodicheskie rekomendacii po gematologicheskim i biohimicheskim issledovanijam u kur sovremennyh krossov. RUP Institut jeksperimental'noj veterinarii imeni S. N. Vyshelesskogo NAN Belarusi, Minsk (in Russian).

Ostapiuk, A. Yu., \& Gutyj, B. V. (2020). Vplyv kadmiievoho navantazhennia na imunnyi status orhanizmu kurei-nesuchok. Visnyk PDAA, 1, 252-259. doi: 10.31210/visnyk2020.01.29 (in Ukrainian).

Ostapyuk, A. Y., \& Gutyj, B. V. (2020). Influence of milk thistle, methifene and sylimevit on the morphological parameters of laying hens in experimental chronic cadmium toxicosis. Ukrainian Journal of Veterinary and Agricultural Sciences, 3(1), 42-46. doi: 10.32718/ujvas3-1.08.

Polumbryk, M., Ivanov, S., \& Polumbryk, O (2014). Antioxidants in food systems. Mechanism of action. Scientific Works of NUFT, 20(4), 19-29 (in Ukrainian).

Reddy, B. S., \& Sivajothi, S. (2017). Avian electrocardiography a simple diagnostic tool. International Journal of Avian \& Wildlife Biology, 2(5), 166-167. doi: 10.15406/ijawb.2017.02.00036.

Shevchuk, M., Stoyanovskyy, V., \& Kolomiiets, I. (2018). Technological stress in poultry. Scientific Messenger of LNU of Veterinary Medicine and Biotechnologies. Series: Veterinary Sciences, 20(88), 6368. doi: 10.32718/nvlvet8811.

Zhurenko, O., Karpovskiy, V., Danchuk, O., \& Kravchenko-Dovga, Y. (2018). The content of calcium and phosphorus in the blood of cows with a different tonus of the autonomic nervous system. Scientific Messenger of LNU of Veterinary Medicine and Biotechnologies. Series: Veterinary Sciences, 20(92), 812. doi: $10.32718 /$ nvlvet9202. 